European journal of American studies

Eleanor Roosevelt at the United Nations: "Diplomacy from Below" and the Search for a New Transatlantic Dialogue

\title{
Raffaella Baritono
}

\section{(2) OpenEdition}

\section{Journals}

Electronic version

URL: https://journals.openedition.org/ejas/11920

DOI: 10.4000/ejas. 11920

ISSN: 1991-9336

Publisher

European Association for American Studies

Electronic reference

Raffaella Baritono, "Eleanor Roosevelt at the United Nations: "Diplomacy from Below" and the Search

for a New Transatlantic Dialogue", European journal of American studies [Online], 12-1 | 2017, document 6, Online since 12 March 2017, connection on 08 July 2021. URL: http://journals.openedition.org/ejas/ 11920 ; DOI: https://doi.org/10.4000/ejas. 11920

This text was automatically generated on 8 July 2021 .

Creative Commons License 


\title{
Eleanor Roosevelt at the United Nations: "Diplomacy from Below" and the Search for a New Transatlantic Dialogue
}

\author{
Raffaella Baritono
}

1 In January 1946 Eleanor Roosevelt, Truman's choice for the American delegation, took part in the first assembly of the United Nations in London. In appointing the former First Lady, Truman recognised that Eleanor Roosevelt, more than others, embodied the ideals that were to underpin that new statement of international order; above all she stood for the values, aims and hopes of a part of American civil society which wished to take part in the administration's decisions and contribute to building a democratic peace-seeking international order. The new administration saw it as crucial to the success of that project that civic associations and non-governmental organizations be a party to it, as most recent works have pointed out ${ }^{\mathrm{i}}$. Eleanor rose to this challenge, though the urge and desire to voice civil society's opinion was to come up against a hard-nosed realpolitik that turned the United Nations into a prime duelling ground between the two superpowers emerging victorious from the Second World War. What I wish to show, in a nutshell, is how Eleanor Roosevelt's ambition to do "diplomacy from below" - voicing the claims of civic associations and the ordinary citizen - soon merged with American public diplomacy and to some extent came to share its values, albeit critically.

2 The definition "diplomacy from below" or bottom-up diplomacy is intended to highlight the citizens' wish to contribute to creating international relations by active participation, cooperating with the traditional diplomatic channels. At times this concept has been confused with "public diplomacy" which is seen as an American innovation. Nicholas J. Cull's definition for this last is "the process by which international actors seek to accomplish the goals of their foreign policy by engaging with foreign publics." This is based on the hardly revolutionary operations of 
"listening, advocacy, cultural diplomacy, exchange diplomacy and international broadcasting." "ii So while the concept of public diplomacy "includes both 'from above' and 'from below' aspects," "iii that of "diplomacy from below" simply refers to bottom-up processes and is distinct from other grass-roots methods. Alan K. Henrikson points out the close connection with the theory of popular sovereignty. ${ }^{\text {iv }}$ Hence the idea that in a public diplomacy setting "even ordinary citizens believe they can legitimately participate." Henrikson thus feels we should speak of "citizen diplomacy," and the idea was taken up by Dwight D. Eisenhower as early as 1956 when calling the White House Conference on Citizen Diplomacy that would lead to the programme that was to become People to People International. The same approach would be adopted by the U.S. Center for Citizen Diplomacy which maintained that "the individual has the right, even the responsibility to help shape U.S. foreign relations 'one handshake at a time"'. Hence Henrikson argued that "the target of citizen diplomacy ... is not the 'states' of other countries, but their 'peoples'. It is a direct society-to-society interaction." $\mathrm{My}$ own view, however, is that "diplomacy from below" places the accent on the complex dynamics of society-state-international organization, as occurs with the United Nations. In this perspective the notion of "diplomacy from below" - which has been employed to cover a number of divergent contexts ${ }^{\mathrm{vi}}$ - may usefully be applied to the role that Eleanor Roosevelt sought to make her own (with the associations' approval). Except that - and this is my point - the official mandate conferred on the former First Lady would eventually restyle that ambition more traditionally as public diplomacy ${ }^{\text {vii }}$.

3 Within the vision of bottom-up diplomacy, as in the stark realpolitik of public diplomacy, it was of fundamental importance that transatlantic dialogue should underlie the new international relations. But Mrs Roosevelt, I feel, stood for an important new development from the kind of Atlanticism pursued by intellectuals like Walter Lippmann: to Eleanor Roosevelt transatlantic relations were both bi-univocal and open to a whole world context. As I shall be arguing later, the line taken by Mary Nolan in her recent book The Transatlantic Century catches this important point. As she puts it, "In the increasingly global twentieth century, Europeans and Americans never gazed only across the Atlantic, and transatlantic relations were triangulated and complicated by competition and conflicts in the Middle East, Asia, and Africa." viii

\section{Not an eccentric choice}

4 On 21 December 1945 Harry Truman told Eleanor Roosevelt he was appointing her a member of the American delegation to the first session of the UN assembly to be held at the beginning of January in London. Heading the delegation was former Secretary of State Edward R. Stettinius. Truman's letter was somewhat vague as to the duties and goals conferred on the delegation, but he concluded with the remark that Eleanor, and all the other representatives of the US government, bore a solemn responsibility to convey that government's deep commitment to the new institution and its lofty task of preserving world peace and laying the foundations of mutual trust, furthering the economic and social wellbeing of the world's peoples ${ }^{\mathrm{ix}}$.

5 Eleanor did not there and then accept: her son would recall how she felt she lacked the diplomatic qualities needed for Truman's mission. Truman's proposal came at a delicate moment in Eleanor's life, a point fraught with uncertainty: how to rearrange her life after years of active political engagement; what new course to give her political 
passions that had by no means subsided with the end of her long stint as First Lady; how above all to carry on the political vision of Franklin Delano Roosevelt which she by and large shared - though in no passive, indeed in a frequently critical, spirit (as over the racial issue); how, in particular, to further the new international order which in effect held out the prospect of a New Deal for the World.

6 In his book The Years Alone, one of Eleanor's closest co-workers, Joseph Lash recalled how Harold Ickes, who had long been a minister in the Roosevelt government, had suggested Eleanor might run for senator in New York State. Other stalwarts of the late President urged her to stand as governor or even President of the United States, seemingly convinced that she alone had the stature, conviction and personality to carry through the reform program that her husband's death had curtailed: for example, proper application of that Second Bill of Rights - FDR's own definition - which was meant to bring the States into line with western social democracy.

7 Eleanor refused all these suggestions for a number of reasons. She was loath to hinder her children's political careers, she felt the time was not yet ripe for a woman president, nor did she wish to accept political office and then find herself shackled by internal Democrat strife and decisions. As she would state in the first interview she gave on board the Queen Elizabeth bound for London, "For the first time in my life I can say just what I want. For your information it is wonderful to feel free." ${ }^{x i}$

8 When Truman's nomination came, in some respects it resolved Eleanor's hesitations. To accept the task was a way of commitment to the most important project she had shared with Franklin. Institutionally, that position would legitimately throw herself into the issues of peace and internationalism on which she had been engaged since the years following World War I. As she wrote in Look, $9^{\text {th }}$ July 1946, in an article explaining "Why I Do Not Choose to Run:" "when I was offered an opportunity to serve on the United Nations organization, I accepted it. I did this ... because it seemed as though I might be able to use the experiences of a lifetime, and make them valuable to my nation and to the people of the world ... I knew, of course, how much my husband hoped that, out of the war, an organization for peace would really develop. It was not just to further my husband's hopes, however, that I agreed to serve in this particular way. It was rather that I myself had always believed that women might have a better chance to bring about the understanding necessary to prevent future wars if they could serve in sufficient number in these international bodies." xii

9 What does need explaining is why Eleanor, reputed by friends and foes alike in 1945 to have great political depth and knowledge of the institutional principles and rules, should think fit to reply as an official United States delegate: "it is wonderful to feel free?" My own answer is that Eleanor could sense, though not fully comprehend the asperities of, the coming bipolar conflict; and she also felt that, political and institutional though it might be, her appointment was a clear token of the importance the new administration attached to what US civil society thought. Actually, as Rowland Bruckner has observed, since 1939 Franklin D. Roosevelt had begun cooperating with non-governmental organizations in "wrestling with postwar human rights objectives." xiii That appointment, therefore, sent a signal to the network of civic associations; it represented "the public," to use a term in vogue with the liberal progressive milieu for which Eleanor stood. I would thus venture to suggest that Eleanor felt a responsibility not so much towards the administration, as towards the sovereign people, the ultimate source of democratic legitimation. The actual state of 
affairs would prove quite different, however: the institutional role would come to outweigh the need to voice the claims of the people. Her position was only apparently "a-political": in actual fact it was the outcome of a process of political education and engagement. Truman's choice was far from eccentric.

\section{Eleanor Roosevelt's commitment to pacifism and internationalism}

10 The First Lady's internationalist commitment dated from the early 1920s. The crucial meeting was with Carrie Chapman Catt in April 1921 at a scheme to rally a woman's crusade for peace. Out of this her links would intensify with the social feminist network involved in issues of peace and social justice: "peace, bread and freedom," to paraphrase Jane Addams' famous pamphlet ${ }^{\mathrm{xiv}}$ : there was the League of Women Voters, the Consumer's League, and the Women's Trade Union League. And with it came her ever-intensifying work inside the New York Democrat party.

11 Throughout the 1920s Eleanor's pacifist battle had hinged on the ever-denied demand that the US join the World Court, as well as on other projects for peaceful settlement of conflict: for instance, the prize offered by Ladies Home Journal editor, Edward Bok, in 1923 for the best peace policy proposal, or the petition for a referendum demanding the United States cooperate with the technical agencies of the League of Nations. The World Court battle and the women's pacifist campaign would also mark her early years as First Lady: in 1935 she held an event at the White House in honour of Jane Addams, and would openly lobby the Senate and the President on behalf of the World Court. In 1935 Eleanor Roosevelt went on the air in favour of ratification two days before the Senate voted, openly standing for an issue she had pursued since the mid-Twenties.

12 From 1933 on, her peace campaign was initially bolstered by news of the situation in Europe - supplied mainly by women from international and pacifist organizations. It was thanks to Eleanor and her network that Franklin had first-hand accounts of events in Nazi Germany that summer of 1933. They came from women pacifists like Alice Hamilton, who had lived in Germany, a guest of Clara Landsberg, the German Jewish suffragette. It was the Nazi threat that finally decided Eleanor Roosevelt to take her distance from the rigidly pacifist position. After a period of public silence on foreign policy issues, in 1938 she published This Troubled World and burned her bridges with pacifism. Eleanor's public silence (her muzzling, according to Blanche Wiesen Cook) not only radicalized her stand on racial and social issues, but went with a growing commitment to the associations campaigning for refugee welcome and urging the government to take a new internationalist stand. While it was chiefly the Kristallnacht that led Eleanor to speak out on events in Germany and join issue with the antiSemitism of certain State Department officials, it was her battle for the World Court that persuaded key exponents of new internationalism that Eleanor might be a prime point of reference. One such was James McDonald, High Commissioner for Refugees at the League of Nations and leader of the Foreign Policy Association. McDonald canvassed Eleanor to lobby the White House and State Department to have American consuls issue visas or not slow down the procedures granting refugees admission to the USA. Likewise Clark Eichelberger, director of the League of Nations Association and other 
internationalist organizations, first contacted Eleanor Roosevelt in the late Thirties when he was invited to the White House along with other prominent youngsters. ${ }^{\mathrm{xv}}$

13 Eleanor not only put pressure on her husband to take a stronger stand or remove obdurately anti-Semitic consuls, but used her daily column My Day to publicize organizations such as the United States Committee for the Care of European Children or the Emergency Rescue Committee. In her piece on 26 June 1940, Eleanor painted the European situation in dramatic colours: "This morning I started out early to attend a meeting of the United States Committee for the Care of European Children. I am thankful beyond words that it is going to be possible to do something for these European children, but my heart is heavy when I think of the tragedies which haunt the lives of many grown people." xvishe went so far as to authorise the last-named committee to use her name if that might expedite immigration bureaucracy, as Ingrid Warburg Spinelli - wife of Veniero Spinelli, brother to the more famous Altiero, one of the founding fathers of European federalism - recalls in her autobiography, where she stresses the First Lady's role and the pressure she brought to bear on the State Departmentrvii.

14 This, then, was the background against which the change occurred in Eleanor Roosevelt. As early as 1934 she was being dubbed a realistic pacifist ${ }^{\text {xviii; }}$ any abstract notion of peace would simply cloud the realization that only a just mechanism might, if necessary, act via a police operation or, in the worst instance, bolster defence systems in readiness for inevitable war. Against the entrenched providentialism and exceptionalism of the isolationists, Eleanor Roosevelt argued that the United States as a nation must look at what was happening across the Atlantic and the Pacific, but without any illusion that she was immune. ${ }^{\mathrm{xix}}$

15 In 1945, hard on her involvement in the movement that led to her visiting war camps in England and the Pacific, Eleanor was thrust by Truman's appointment into what her autobiography called "the most wonderful and worthwhile experience in my life $\mathrm{x}^{\mathrm{xx}}$."

\section{Public diplomacy or diplomacy from below?}

16 To some extent Truman's decision to include Eleanor in the official delegation was an act of public diplomacy, a sop to public and international opinion. Her fame as a liberal, attentive to questions of social and racial justice, her penchant for listening to others, her conviction that American policy must favour the expansion of democracy and rights without imposing a political model, would make her an icon of political democracy, especially in the work she did on the Commission for Human Rights. Truman himself admitted as much: when Eleanor died, and he commented on Eisenhower's decision to leave her out of future American delegations to the United Nations, Truman said "I made use of her. I told her she was the First Lady of the World." In a 1954 letter Truman wrote: "She has been one of our most effective forces against Communist propaganda in many vulnerable spots in the world." ${ }_{x \times i}$

17 Back in 1945, however, public diplomacy in the broadest description of it - viz. "the whole range of communication, information and propaganda under control of the government"xxii - was, as many scholars have pointed out ${ }^{\text {xxiii }}$, beginning to shape up around a public-private network involving a sizable involvement of civic associations and non-governmental organizations. This forestaste of public diplomacy in action 
came at the San Francisco Conference in April 1945, which involved 42 "pressure groups" and other invited observers after America's absence from Dumbarton Oaks had been heavily criticised by religious groups, labour, women's associations and internationalist movements.

18 Around the issue of setting up and bolstering the United Nations there was a climate of internationalism that was no longer a matter for the elite: it spread within civil society through the work and commitment of the civic associations. As a pamphlet for the League of Women Voters put it, "If we accept the premise on which the United Nations Charter is based ... then we must roll up our sleeves and to go work to make the United Nations Organization work, and to develop it eventually into a world organization with its own measure of sovereignty"xiv.

19 The creation of the Division of Public Liaison inside the State Department in 1944 was connected with this wartime strategy of involving associations and groups that wanted to seize the "second chance." ${ }_{\mathrm{xxv}}$ In 1942 Charles Eichelberger, one of Eleanor Roosevelt's most constant interlocutors, wrote to the then Secretary of State Summer Welles that they should mobilise groups and sectors of the population like "labour, business, professional and housewives' associations for assistance in an educational campaign." ${ }^{x v i}$ As Christy Jo Snider remarked in an article a few years back, there were three reasons inclining the US leadership to involve and then incorporate nongovernmental associations in the UN charter on the basis of article 71: first of all, the ability of various groups to influence public opinion; second, "American leaders valued these organizations' ability to research, study, and organize international programs concerning world problems without touching limited governmental resources;" and third, "U.S. foreign policy elites were willing to bring transnational interest groups into the United Nations so that global government would have some control over NGO activities."xxvii Relations with the NGO associations were thus crucial to any democratic redressing of the international order.

20 One of the officials from the Division of Public Liaison, Chester Williams, wrote to congratulate Eleanor on her nomination as UN delegate:

21 Some of us who have been cooperating with the national organizations represented by consultants and observers at San Francisco feel that American study and discussion of UNO could now be stimulated if the President and the Secretary of State would invite nation-wide discussion of the important world issues and the proper American position on such issues. Even more than discussion, we hope that the people might be urged to formulate their views and submit than directly or through their national organizations to the Department. ... One of my special responsibilities in the Department is to promote understanding of UNO and UNESCO through all channels of communication, especially through organized groups and the public platform.

There followed a description of the plans afoot to circulate material and involve scholars, foreign policy experts journalists, etc. xxviii. An "experiment in democracy" was how this was described by Dorothy Robins, secretary of the association created by Eichelberger ${ }^{\mathrm{xxix}}$. 
23 With her political and intellectual background, Eleanor Roosevelt appeared someone who, more than other men and women, might act as a link between the elites and the grass roots movements. As Bruckner has observed, "Her appointment brought instant credibility to the department's human rights program from internationalist groups who knew of her work against prewar isolationism, her efforts on behalf of wartime refugees, and her support for postwar peace with the Soviet Union." ${ }^{x x} \mathrm{Her}$ appointment was ratified by the Senate with only one opposing vote - Senator Theodore Bilbo from Mississippi, who could not accept her position on civil rights though she was also criticised by key names like John Foster Dulles, who thought her too liberal, or William Fulbright, who considered it disrespectful to the United Nations to send someone so little versed in foreign policy ${ }^{\mathrm{xxxi}}$. Against this, however, there was an enthusiastic reception by associations and public opinion, albeit with a sprinkling of adverse comments.

24 The congratulatory letters Eleanor received provide an instructive picture of how American public opinion stood on the eve of the first session of the United Nations. With emotion still running high at the loss of FDR, there naturally prevailed the idea of Eleanor as the one best fitted to carry on the president's international vision; her appointment seemed a tribute to the prime mover of the United Nations. At the same time, though, as the Atlanta Sunday Constitution wrote, "she, better than perhaps any other person, can represent the little people of this country and, indeed, of the world." xxxii Mynnette Hastings from the National Congress of Parents and Teachers wrote: 'It has been the hope of endless numbers of the 'folks' of this country that a woman - one of wide sympathies and deep understanding - might serve as one of our representatives when a new world order was being built on the wreckage of the old.... You could continue serving the people of this country and also extend your influence to those of other lands as well." xxxiii

25 No less important was the weight attached to a woman being elected. A letter sent to Truman spoke of the satisfaction of women - and Democrat women in particular and how Mrs Roosevelt not only possessed "comprehensive understanding of World Affairs" but "the courage to speak for the many millions of plain people both at home and abroad, whose interests are pleading for understanding and who fervently desire a wise solution of the problem that lead to war"xxiv. The appointment acted as a kind of acknowledgment of women's efforts for peace over the decades and their search for new ways of viewing the international set-up. This clearly transpires from letters written by women from the associations - the General Federation of Women's Clubs, the Women's Action Committee and the National Council of Jewish Women, to mention but a few - that had urged President Truman to include at least one woman on the delegation; and likewise by admiring individual citizens, men and women. R. Wimberly, on the South Carolina section of the AAUW, said that "a new day has dawned for the womanhood of the world as you become the spokesman of American women dedicated to the task of winning the peace and of affecting a collective security that will function adequately"xxxv. Roosevelt herself told the press how "she felt her appointment as a delegate to the United Nations Organization meant that there was a 'demand for a woman' member of the United States delegation and that she 'naturally' would accept it." ${ }^{x x x v i}$

26 Not everybody saw eye to eye, of course. Hugh Macbeth, chairman of the United Races of America, was himself congratulatory ("you are the best representative which 
the American people have in the list of delegates to the United Nations Organization"), but saw fit to include a cutting from the Los Angeles Times that deemed the appointment "unfortunate." Clearly echoing the sentiments of conservative public opinion, the newspaper thought that "she seems misplaced in a post which requires diplomacy, and a guarded tongue," whereas "on various occasions she has made utterances which tended to promote bad feelings between races. Good judgment and good taste appear alike alien to her make-up. ... There are plenty of well educated, well qualified American women who could be named to such a post and would fittingly represent their country. But Mrs. Roosevelt is not among them." $x x x v i i$

27 To my mind, such letters showed that Eleanor not only continued to be appreciated, but was seen as an important reference person - a privileged interlocutor, almost "one of us" - by the association leaders. As a matter of fact, Eleanor's relationships with civic groups and associations (most of them nonpartisan even if some were lined up with liberal values) dated many decades back. She was also member of some of them or she had served in their board of directors. Therefore, her appointment would not only guarantee they were involved, but was also seen as some kind of legitimation for bottom-up internationalism. Internationalism from below had been marginalised during the 1920s and 1930s, but began to gain new vitality after 1939, consisting above all in a new "take" on transatlantic relations, rather than an interest in other geopolitical areas. The difference was that, as a member of many associations that were girding themselves to contribute to the new international organization from inside, Eleanor Roosevelt could voice their arguments and objectives, turning the notion of "diplomacy from below" into concrete fact.

28 For example, the National Federation of Business and Professional Women Clubs wrote to her: "May we take this opportunity to assure you that the 91,000 members of this Federation stand ready to support any method of implementation the work and accomplishment of The United Nations Organization which, in your judgment as a delegate, seems judicious. Our Federation has stood energetically behind all the preparation for this new world organization and has been outspoken in favour of placing the responsibility for the use of Atomic Energy in the United Nations Organization." Anna Lord Strauss, from the League of Women Voters, concluded her letter outlining her association's priority points: "The national Board feels that part of its responsibility is to summarize the trend of League thinking so that it may be presented to those who are responsible for formulating our policy. May I assure you that our members are watching with deep interest and concern the evolution of the United Nations." ${ }_{x x x v i i i}$

29 Eleanor immediately contacted the civic associations, volunteering her readiness to carry their issues into the international arena. Before setting off for the first UN assembly in London, she asked various associations to let her know their suggestions and how they felt about their own particular hobbyhorses. Many of them did send proposals, some detailed, while all expressed a keen desire to be in on this joint effort. This was not just a first flush of enthusiasm, the sense of a new epoch paying tribute, as it were, to the president's memory and espousing his dearest cause. To Eleanor the importance of grassroots work and the link with the associations would be constant features of her commitment inside and outside the United Nations throughout the 1950s. Witness Eleanor's work inside Americans for the United Nations after 1953 (when Eisenhower decided not to reconfirm her mandate). She and the association 
were intent on keeping up interest in the United Nations, even at a time of growing disaffection; they got up educational campaigns in schools and communities, projects for United Nations Days, and so on. ${ }^{\text {xxix }}$

30 As 1945 closed and 1946 opened, many issues emerge from her correspondence, regarding the specific concerns of the various interest groups and associations. Some questions are raised by all associations: primarily, establishing an Atomic Commission, a trusteeship for the colonial territories (obviously a close concern of the NAACP, together with the race discrimination issue, but also espoused by the League of Women Voters, the AAUW, the AAUN etc.), education and promotion of culture, and above all the issue of human rights. For example Clark Eichelberg, representative of the Commission to Study the Organization of Peace, urged the General Assembly to set up a committee on atomic energy and on human rights, as well as tackling issues connected with trusteeship. Walter White, from NAACP, raised the subject of a settlement for the former colonies. Helen Reid, from the American Association of University Women, likewise argued for regulation of atomic energy and also raised the question of female emancipation and the need to promote a "constructive foreign policy." Women's rights, monitoring atomic energy, human rights, and education policy were also central points in a letter sent by Constance Sporborg, president of the General Federation of Women's Clubs ${ }^{\mathrm{xl}}$.

31 Mynnette Hastings recalled, for example, how the subject of human rights was added to the San Francisco agenda after pressure from civic associations. She wrote: "While serving as a consultant at the San Francisco Conference, we not only supported the foregoing items [namely, the creation of UNESCO, the promotion of social policies in the fields of health care, child labor, social work and so on] but also the inclusion of 'human rights' in the various chapters of the UNO Charter; we also helped support the efforts of the women from other lands in urging that the word 'sex' be included in the Charter so that there might be no discrimination against them because of 'sex' as well as 'race or religion"'. xli A demand voiced by all was that the Economic and Social Council be strengthened and, of course, that a High Commission on Human Rights be set up.

32 Eichelberger would later note: "Turning from security to human rights, our research affiliate, the Commission to Study the Organization of Peace, has had a subcommittee working on the subject of human rights. We spearheaded the movement at San Francisco for the provision in the Charter that the Economic and Social Council must appoint a commission on human rights. We have prepared a brief memorandum giving the views of our committee as to how we believe the commission on human rights should be appointed and how it would proceed. Some of the delegates to the Preparatory Commission take the view that the commission would be more responsible if composed of Governmental representatives. Another view could well be that it would be more courageous if composed of distinguished individuals. We recommend as a compromise between the two ... We propose that Governments place for nomination the names of individuals to serve on the human rights commission ...." "lii

зз But it was the General Secretary of The Church Peace Union, Henry Atkinson, whose explicit call for "security against want" most clearly stated a key issue of that Second Bill of Rights of Rooseveltian memory, central to the project for what was envisaged as a "world new deal." xliii Eleanor Roosevelt echoed the sentiment in a 1953 pamphlet: "Philosophically minded UN people emphasize the point that the Charter's 
wording starts 'We the people.' Not 'We the Governments, the Dictators, Kings, Presidents or what not."xliv

\section{Cold war constraints}

Eleanor Roosevelt's efforts within the United Nations thus alternated constantly between work on commissions and relations with associations or broader public opinion via her daily column My Day in which she reported on events inside the United Nations $^{\mathrm{xlv}}$. It was a labour of mediation often based on political realism which prevented her from espousing radical positions like Carrie Chapman Catt's on disarmament, or bringing internal political bones of contention into an international organization. One example here was her initial resistance to a commission being set up on the condition of women; this is partly explained by the coolness of many American women activists, especially those gravitating round the Women's Bureau who feared any airing of the laws on social protection ${ }^{\mathrm{xlvi}}$.

35 Nonetheless, Eleanor Roosevelt's experience at the United Nations showed how her ambition to conduct diplomacy from below clashed with the needs and restraints imposed by her official role. My view is that in her time at the United Nations Eleanor Roosevelt took the same line as when First Lady: she sought to be a bridge between political power and civil society; she saw herself as a spokeswoman for public opinion, a listener, an interpreter of claims that needed to be laid before the organs of political decision-making. One might paraphrase Peter Willetts, and say that Eleanor acted as "the conscience of the world."

36 To borrow a definition introduced by Bernice Robnett à propos of AfricanAmerican women ${ }^{\text {xlvii }}$, her ambition was to play the role of bridge-leader, a circular form of leadership, expressing the kind of women's politics that had shaped her own political background. This was a function she was continually to cite throughout her career, as I have shown in an essay dealing with Eleanor's 1950s trips to so-called third-world countries ${ }^{\text {xlviii. }}$.

37 In a speech given in 1953, she said: "Where, after all, do universal human rights begin? In small places, close to home - so close and so small that they cannot be seen on any map of the world. Yet they are the world of the individual person: The neighbourhood he lives in; the school or college he attends; the factory, farm or office where he works. Such are the places where every man, woman, and child seeks equal justice, equal opportunity, equal dignity without discrimination. Unless these rights have meaning there, they have little meaning anywhere. Without concerted citizen action to uphold them close to home, we shall look in vain for progress in the larger world."xlix

38 Her battle over the founding of UNESCO, and the issue of refugees and human rights initially proved irksome to the State Department. So much was admitted by the very person who should have been the inside reference person, Archibald McLeish, who warned her: "I am worried about the Department's attitude toward the United Nations Educational, Scientific and Cultural Organization, the Constitution of which was drafted at our London meeting in November. The Department is traditionally scornful of that whole side of foreign relations - a side which is increasingly important from day to day." 
39 Eleanor Roosevelt's own account of the reception she got from other delegation members is here significant. She was assigned to Committee Three which dealt with economic, social and humanitarian issues. The appointment was decided by other members of the delegation without realising that such issues - especially that of refugees and their right to choose whether to go home or not - would be the scene of the first deadlock between the US and the Soviet Union. Nominated chair of the Nuclear Commission on Human Rights, Eleanor Roosevelt would play a prominent part in this breach, showing a flair for political mediation. The experience would alter her originally cooperative approach to the Soviets and reinforce her anticommunism, though she never saw them as any kind of race apart.

40 UN official James Frederick Green, who worked with Eleanor Roosevelt, felt that she could not be considered a 'cold warrior' even of a reluctant kind. To Green, "she wasn't as strongly anti-Soviet and cold warrish as, say, John Foster Dulles was, or others in that period, but she fought the good fight all the way through....I don't think she had kind of the devil theory of communism that Dulles and others had"li.

41 The battles within the Human Rights Commission would curb Eleanor's ambition to conduct "diplomacy from below." She herself admitted this: "during the entire London session of the Assembly I walked on eggs. I knew that as the only woman on the delegation I was not very welcome." Yet her diplomacy mixed with firmness in handling the refugees controversy won congratulations from Dulles and Vandenberg: they confessed they had been against appointment of her, but 'we must acknowledge that we have worked with you gladly and found you good to work with. And we will be happy to do so again'. lii

42 Just as scholars of the state-private network have revealed dynamics of co-optation as well as cooperation between civic associations and US government, so with Eleanor's cause: her "circular vision" of things soon found it had to bow to the needs and strategies of US foreign policy. In the end the female and professional associations' "cooperative relationship" was forced to adapt to reality and give way before the power of cold war logic. Progressively, they would be absorbed in the politics of American propagandaliii, just as the vision of multilateral internationalism would be overshadowed by policies based on national interest and national security ${ }^{\text {liv }}$.

43 Eleanor realised all too soon that her sense of "feeling free" was wishful thinking. As she admitted, "In London, fortunately, I agreed with the State Department position. But later I learned that a delegate does have certain rights as an individual and on several occasions I exercised my right to take a position somewhat different from the official viewpoint."lv

44 This dilemma concerned many issues in which she was involved, from the problem of trusteeship and the recognition of Franco regime to women's role in the UN organization, just to name a few. However, her dilemma is known to have become acute when it came to racial issues which were probably the cause closest to her heart. To the Afro-American movements, creation of the United Nations was an opportunity to voice their claims as part of a broader transnational movement against colonization. As DuBois wrote to Bethune during the San Francisco Conference, "The Negro in America has an unprecedented opportunity in this Conference on a World Security Organization, to lift his sights to encompass a world view of the problems of peace and to think in unison with the representatives of forty-six nations... Through this Conference, the Negro becomes closely allied with all the darker races of the world, but 
more importantly, he becomes integrated into the structure of the peace and freedom of all people, everywhere." America's UN delegation, Walter White reminded her of the issues close to the heart of the NAACP especially the campaign to abolish "the entire colonial system," and likewise to heed the minorities when choosing staff for the international organization and include the Afro-American colleges in the student exchange programme. ${ }^{\text {lvi }}$ This was Eleanor's golden opportunity to espouse the aims of civic associations and the Afro-American movement in particular. Yet when DuBois and White, as members of the NAACP, asked her to support the 1947 petition "Statement on the Denial of Human Rights to Minorities in the Case of the Citizens of Negro Descent in the USA," Mrs Roosevelt allowed her official position to prevail over her personal beliefs. On being presented to the Secretary General, the document caused ructions between the United Nations and the State Department, especially once third-world representatives and communist delegations took up the debate. .viii $^{\text {vil }}$

45 As Eleanor wrote to White, there was clearly no question of not supporting the position, but a "proper procedure" needed to be struck. When White telegrammed for her to be present at a meeting convened to present an Appeal to the World at the United Nations, she turned him down, bowing to strong state department pressure. "I am very sorry that I can not be with you tomorrow morning at twelve o'clock. As an individual I should like to be present, but as a member of the delegation I feel that until this subject comes before us in the proper way, in a report of the Human Rights Commission or otherwise, I should not seem to be lining myself up in any particular way on any subject. It isn't as though everyone did not know where I stand. It is just a matter of proper procedurelix". The decision widened the rift between Eleanor Roosevelt and DuBois, though later she did help White and DuBois behind the scenes. An article in The Nation would comment: "Mrs. Eleanor Roosevelt ... is on the board of directors of the NAACP. Since she offered no constructive proposal of her own, she must have had to subordinate her well-known personal feelings to this country's historical anti-Negro policy. Her dilemma is not new. It has frustrated many of our able political leaders." ${ }^{1 \times}$

46 Her many speeches praising the work being done by the Commission on Human Rights - beginning with one of the most important: the address to the Paris Sorbonne in 1948 - in their turn needed frequent negotiation with the State Department who were constantly suggesting she remove the more problematic passages. Eleanor Roosevelt's great political skills were nonetheless brought to bear on the cultural cold war and the confrontation between democracy and totalitarianism. She was thus able to ease tension, unravel knots and in the end gain approval for the Declaration of Human Rights with the Soviet bloc, Saudi Arabia and South Africa abstaining. She also succeeded in her idea of a Declaration that was a manifesto of intent, on the model of the Atlantic Charter, and not a binding charter.

47 As Dean Acheson wrote to Eleanor in 1952 when she travelled to the Middle East, India and Pakistan, "your many speeches and personal appearances outside the Assembly, in which you presented the American viewpoint most successfully to the European public, were a major contribution to our general effort. I am sure, too, that your present trip will be a means of bringing the American views effectively to some of the Far Eastern peoples." ${ }^{1 \times i}$ 
48 Acheson's message brings me to my last point: the importance of transatlantic relations in Eleanor Roosevelt's vision of things. The focus of the associations and the internationalist movement lay mainly in the Atlantic arena, though the issue of colonialism was kept alive, especially by the Afro-American associations.

\section{The transatlantic dimension of Eleanor Roosevelt diplomatic vision.}

Eleanor's political background, rooted in women's progressive pacifist reformism, had gained a cosmopolitan and transnational quality and this reflected on those values which formed the basis of her political and intellectual vision. I am not able to explore this issue at length, but Eleanor's maturing experience was coloured by Atlantic Crossings, that Atlantic dimension which, Daniel Rodgers argues, was a privileged area of fertile exchange between intellectuals, reformers and social workers from America and Europe (especially Britain) on issues of reform and social justice. This phenomenon dated from the early $20^{\text {th }}$ century and in the 1940 s received a new founding text in the Atlantic Charter. ${ }^{\text {lxii }}$

50 Relations between the American and British delegates had been very close during the San Francisco Conference, despite tension at their two differing approaches to the colonies issue. Reinhold Niebuhr, the theologian and one of the founders of Americans for Democratic Action in 1947, comments on this incomprehension between American liberals and their British counterparts: "American liberalism is equalitarian without understanding there are functional and fortuitous inequalities in even the most ideal community, whether National or International... British idealism thinks primarily in terms of the responsibilities of power; American idealism thinks primarily in terms of the disavowal of power in order to escape its corruptions." "xiii

51 Intellectually, too, a significant swath of US liberalism to which Eleanor belonged and gave support (movements like Union for Democratic Action created in 1941, which would give rise to Americans for Democratic Action in 1947) continued to argue the inter-connectedness of domestic politics and international politics. They saw the transatlantic relationship as the basis for any expansion of the liberal democratic model. Again, a role was once again being played by the civic associations committed to the internationalist movement: there was the American Association of University Women, the League of Women Voters and the National Federation of Business and Professional Women's Clubs; though when the Cold War set in after 1946, the issues of democracy and anti-communism came to overshadow their internationalism, as we have mentioned. In 1945-46, for example, the articles published in the Journal of the American Association of University Women highlighted the plight of the devastated countries of Europe ${ }^{\text {lxiv }}$ and invited members to forge links of cooperation and to help with reconstruction.

52 In one such article, Helen Dwight Reid listed ten ways in which each section of the association should contribute to international rebuilding. The same article contained a study on the documents underpinning the new order, including the San Francisco Charter, the Bretton Woods agreement and the Atlantic charter. It went on to raise the possibility of international cooperation, in light of the urgent need to restore dialogue and transatlantic exchange of knowledge. Groups of immigrants present in the 
community might be enlisted, while films and documentaries could be projected showing the situation in Russia, Great Britain and Latin Americalev. But then, of course, as Deborah Stienstra has pointed out, "trans-Atlantic culture" had been a feature of women's politics since the 1790s.

53 While emphasising the deep bond between the United States and Great Britain, Eleanor Roosevelt spoke of interdependence, over and above the need for cooperation and rebuilding: "interdependence is what we have to learn if we are going to be willing to pay the price for peace."

54 It was the notion of interdependence that led Eleanor to broaden the canvas to include other peoples, including the Soviet countries. In a Washington speech given in March 1946 she continued: "I am not minimizing what Great Britain did for us when she stood alone for a whole year ... but we should not have our vision clouded by thinking that the English-speaking people of the world, despite their strength, can get along without the far greater number of people that are not English-speaking." "lxvi Yet only two years later that spirit of trust seemed to have been shaken: it was transatlantic dialogue that was to be strengthened, Anglo-American relations in particular. When she spoke at Oxford in 1948, Eleanor Roosevelt claimed there were more than historical ties between the States and Britain: what united the two nations was the fact that their peoples wanted peace; above all they wanted freedom, and "that combination of peace and freedom is difficult to achieve in some parts of the world." Such solidarity should be seen as a model for other peoples: "Solidarity between our two nations and other states bordering the Atlantic, will, we hope, spell greater economic security, better living conditions for the people of our nations and therefore a gradual demonstration that in freedom, the democracies can develop and bring about through the action of the people themselves, the same ends which the Soviet states feel can only be brought about through the wisdom of a few people at the top level and the control of the life of their people."1xvii

55 The complicated mirror relationship across the Atlantic between the young American society and that beloved yet hated "Europe" lay at the root of American and European identity-building. It would go on existing, even if the image the mirror reflected was destined for other eyes: those of Eastern European peoples, and increasingly the new nations appearing on the international scene.

\section{Conclusion}

Eleanor Roosevelt responded enthusiastically to Truman's appointment of her to the UN delegation. The new role enabled her to pursue her ideals of democracy and internationalism, and to go on cultivating relations with the civic associations - the warp and weft of the American democratic model. What is more, her membership of many associations working in a climate of enthusiasm to make the international framework more democratic - with a view to seizing this 'second chance' - made her the ideal interlocutor to voice their claims and implement their goals.

57 Although the deepening Cold War gradually made Franklin D. Roosevelt's vision of a global order recede, Eleanor Roosevelt's commitment to promoting democracy and human rights never lost sight of the broader canvas, be it Eastern Europe or the postcolonial situation. 
58 Nonetheless, her ambition to practise "diplomacy from below" was curbed by the harsh reality of bipolar conflict. Ultimately what prevailed was her increasingly significant role within the strategies of public diplomacy being implemented by the United States government.

59 By now First Lady of the World, Eleanor reasoned in terms of a circular relationship; and although she can hardly be seen as a forerunner of "celebrity diplomacy" - to use Kofi Annan's recent phrase ${ }^{\text {lxvii }}$-, nonetheless unwittingly, even unwillingly, despite her open dislike of the contortions new-deal liberalism was indulging in at home and abroad, in the end she became a "global Eleanor": the benevolent, supportive face of American hegemony, the example of an open society, tolerant of criticism and dissent, in which guise it formed a strongly seductive model.

\section{NOTES}

i. See, among others, Christy Jo Snider, "The Influence of Transnational Peace Groups on U.S. Foreign Policy Decision-Makers during the 1930s: Incorporating NGOs into the UN," Diplomatic History, 27, 3 (June 2003), 377-404;Helen Laville and Hugh Wilford, eds., The US Government, Citizen Groups and the Cold War. The state-private network (London: Routledge, 2006); Andrew Johnstone, “To Mobilize a Nation. Citizens' Organizations and Intervention on the eve of World War II,"in Andrew Johnstone and Helen Laville, eds., The US Public and American Foreign Policy (London: Routledge, 2010), 26-40;Andrew Johnstone, Dilemmas of Internationalism. The American Association for the United Nations and US Foreign Policy, 1941-1948 (London: Ashgate, 2009).

ii. Nicholas J. Cull, "Public Diplomacy: Taxonomies and Histories," Annals, AAPSS, 616 (March 2008): 31-32.

iii. Barry Sautman and Li Ying, "Public Diplomacy from Below: The 2008 'Pro-China' Demonstrations in Europe and North America," CPD Perspectives on Public Diplomacy, paper 11 (2011): 12.

iv. Alan K. Henrikson, "Sovereignty, Diplomacy, and Democracy: The Changing Character of 'International' Representation-from State to Self?," The Flectcher Forum of World Affairs, Special Edition, 37, 3 (2013): 112-113.

v. Alan K. Henrikson, "Sovereingty, Diplomacy, and Democracy”, 119.

vi. See, for instance, Renaud Morieux, "Diplomacy from Below and Belonging: Fishermen and Cross-Channel Relations in the Eighteenth Century," Past and Present, 202 (February 2009): 83-125; Stephen Brier and Ferdinando Fasce, "Italian Militants and Migrants and the Language of Solidarity in the Early-Twentieth-Century Western Coalfields," Labor: Studies in Working-Class History of the Americas, 8, 2 (2011): 89-121.

vii. Giles Scott-Smith, "Mapping the Undefinable: Some Thoughts on the Relevance of Exchange Programs within International Relations Theory," Annals, AAPSS, 616 (March 2008): 173-195; Geoffrey Cowan and Amelia Arsenault, "Moving from Monologue to Dialogue to collaboration: the Three Layers of Public Diplomacy," Annals, AAPSS, 616 (March 2008): 10-30; Eytan Gilboa, "Searching for a Theory of Public Diplomacy," Annals, AAPSS, 616 (March 2008): 55-77; Nicholas J. Cull, "Public Diplomacy: Taxonomies and Histories," Annals, AAPSS, 616 (March 2008): 31-53. See also Nicholas J. Cull, The Cold War and The United States Information Agency: Propaganda and Public Diplomacy, 1945-1989 (Cambridge: Cambridge University Press, 2009). 
viii. Mary Nolan, The Transatlantic Century. Europe and America, 1890-2010 (Cambridge: Cambridge University Press, 2012): 9.

ix. Truman to Eleanor Roosevelt, 21 December 1945 in The Papers of Eleanor Roosevelt. The Human Rights Years 1945-1948, ed. by Allida Black, vol. 1 (Charlottesville, VA: University of Virginia Press, 2010): 158-59

x. Joseph P. Lash, Eleanor: The Years Alone (New York: Norton, 1972)

xi. Memorandum press conference held by Mrs. Eleanor Roosevelt on Board of MS Queen Elizabeth Conference room, Jan. 3, 1946, in The Papers of Eleanor Roosevelt, 1945-1962, UN Correspondence and Publication, Part I, reel 15, Roosevelt Study Center, Middelburg, NL

xii. Eleanor Roosevelt, “Why I Do Not Choose to Run,” Look, July 9, 1946, http://www.gwu.edu/ verpapers/documents/articles/whychoosenottor...

xiii. Rowland Brucken, A Most Uncertain Crusade. The United States, the United Nations, and Human Rights, 1941-1953 (Dekalb, Ill.: Northern Illinois University Press, 2014), 16.

xiv. Jane Addams, Peace and Bread in Time of War (1922) (Urbana and Chicago: University of Illinois Press, 2002).

xv. Interview with Mr. Clark Eichelberger by Dr. Thomas F. Soapes, Oral Historian, on November 15, 1977 for Franklin D. Roosevelt Library, Eleanor Roosevelt Oral History Transcripts, Roosevelt Study Center, Middelburg, NL.

xvi. Eleanor Roosevelt, "My Day", June 26, 1940, My Day Project, Electronic Edition, Eleanor Roosevelt Project, http://www.gwu.edu/ erpapers/myday/displaydoc.cfm?_y=1940\&_f=md055616. See also "My Day" columns published on September 6, 1940; September 21, 1940, October 11, 1940, November 28, 1940, February 28, 1941, May 29, 1941, August 16, 1941, May 5, 1942, September 5, 1942, October 8, 1942, May 14, 1943. https://www.gwu.edu/ erpapers/myday/ xvii. Ingrid Warburg Spinelli, Il tempo della coscienza. Ricordi di un'altra Germania 1910-1989 (Bologna: Il Mulino, 1994), 114.

xviii. Quoted in Jason Berger, A New Deal for the World: Eleanor Roosevelt and American Foreign Policy (New York: Social Science Monographs, 1981), 12.

xix. Eleanor Roosevelt, This Troubled World (New York, Kinsey, 1938).

xx. Eleanor Roosevelt, The Autobiography of Eleanor Roosevelt (New York: HarperCollins, 1961), 299. xxi. Truman to Morgenthau, Sept. 25, 1954, in Eleanor and Harry: The Correspondence of Eleanor Roosevelt and Harry S. Truman, ed. by Steve Neal (New York: Scribner, 2002), 225.

xxii. Ibid., 310 .

xxiii. See, among others, Frances Stonor Saunders, Who Paid the Piper? The CIA and the Cultural War (New York: Granta, 2000); Helen Laville, Cold War Women. The International Activities of American Women's Organisation (Manchester: Manchester University Press, 2002); Elizabeth Borgwardt, A New Deal for the World. America's Vision for Human Rights (Cambridge, Mass.: Harvard University Press, 2005).

xxiv. Quoted in Elizabeth Borgwardt, A New Deal for the World, 70.

xxv. Robert Divine, Second Chance. The Triumph of Internationalism in America During World War II (New York, Atheneum,1967)

xxvi. Andrew Johnstone, Dilemmas of Internationalism, 34-5.

xxvii. Christy Jo Snider, “The Influence of Transnational Peace Groups”, 379.

xxviii. Chester Williams, Dpt of State, to ER 25 December 1945 in The Papers of Eleanor Roosevelt, Part I, reel 1.

xxix. Dorothy B. Robins, Experiment in Democracy. The Story of U.S. Citizen Organizations in Forging the Charter of the United Nations (New York: The Parkside Press, 1971), 104.

xxx. Rowland Bruckner, A Most Uncertain Crusade, 93.

xxxi. James B. Reston, "UNO Delegates Confirmed But Policy Is Challenged," New York Times, 21 December, 1945; "Senate Confirms U.N.O. Delegation," Los Angeles Times, 21 December, 1945; "UNO Delegates Given Senate Confirmation," The Washington Post, 21 December, 1945. See also 
Interview with Mrs. Helen Gahagan Douglas by Ms. Emily Williams, Oral Historian on January 22, 1979, Eleanor Roosevelt Oral History Transcripts, Roosevelt Study Center, Middelburg, NL

xxxii. In ER Papers, UN Corr., Part I, Reel 1

xxxiii. Mynnette Hastings to Eleanor Roosevelt, December 26, 1945, in The Papers of Eleanor Roosevelt, 1945-1962, UN Correspondence and Publication,Part I, Reel 1.

xxxiv. Eva Lane to Truman, December 20, 1945 attached to Eva Lane (secretary of Berkely Women's Forum) to Eleanor Roosevelt, 21 December 1945,in The Papers of Eleanor Roosevelt, 1945-1962, UN Correspondence and Publication, Part I, reel 1.

xxxv. See letters to Eleanor Roosevelt from Constance A. Sporborg, 28 December 1945; Mrs. Joseph Welt 21 December 1945, R. Wimberly 21 December 1945; Mary Ballard (21 December1945?), Ella Boole, 10 January. 1946; Dorothy Elmhurst 4 January 1946, in The Papers of Eleanor Roosevelt, 1945-1962, UN Correspondence and Publication, Part I, reel 1.

xxxvi. "Mrs. Roosevelt Accepts", The Washington Post, December 21, 1945.

xxxvii. Hugh Macbeth to Eleanor Roosevelt, 21 December 1945, in in The Papers of Eleanor Roosevelt, 1945-1962, UN Correspondence and Publication, Part I, reel 1. "One Unfortunate Choice for United Nations Delegate," Los Angeles Times, 21 December, 1945.

xxxviii. Josephine Schain and Mildred Burgess to Eleanor Roosevelt, 28 December 1945; Anna Lord Strauss to Eleanor Roosevelt, 3 December, 1946, in The Papers of Eleanor Roosevelt, 1945-1962, UN Correspondence and Publication, Part I, reel 1; see also Henry Atkinson to Eleanor Roosevelt, 27 December 1945; A.S. Goss, to Mrs. William Sporborg, 18 December 1945,in The Papers of Eleanor Roosevelt, 1945-1962, UN Correspondence and Publication, Part I, reel 1.

xxxix. Interview with Mr. Clark Eichelberger by Dr. Thomas F. Soapes, Oral Historian, on November 15, 1977 for Franklin D. Roosevelt Library, Eleanor Roosevelt Oral History Transcripts, Roosevelt Study Center, Middelburg, NL.

xl. See letters addressed to Eleanor Roosevelt by Carrie Chapman Catt 28 December 1945; Walter White 28 December 1945; Helen Dwight Reid 28 December 1945; Mrs. William Hastings 27 December 1945; Esther Lape, 21 December 1945; Vera Whitehouse 28 December 1945; Constance Sporborg 28 December 1945; Henry Atkinson 27 December 1945; C. Eichelberger 28 December 1945, in The Papers of Eleanor Roosevelt, 1945-1962, UN Correspondence and Publication, Part I, reel 1.

xli. Mrs. William Hastings to ER 27 December 1945. See also, Rowland Bruckner, A Most Uncertain Crusade, 57.

xlii. Clark Eichelberg, UN: The First Ten Years (New York : Harper \& Brothers, 1955)

xliii. Henry Atkinson to Eleanor Roosevelt, December 27, 1945.

xliv. Eleanor Roosevelt and William DeWitt, UN: Today and Tomorrow (New York: Harper \& Brothers, 1953).

xlv. See for instance Chapman's request to recommend Dorothy Kenyon's appointment to UN Commission on the Status of Women, Carrie Chapman Catt to Eleanor Roosevelt, 7 May 1946, in The Eleanor Roosevelt Papers, I, 305-6. Or how Eleanor Roosevelt dealt with the issue of the recognition of Franco's regime and her correspondence with Freda Kirchwey and others. See The Eleanor Roosevelt Papers, I, 411-417.

xlvi. Helen Laville, “A New Era in International Women's Rights? American Women's Associations and the Establishment of the UN Commission on the Status of Women," Journal of Women's History, 20, 4 (2008), 34-56.

xlvii. Belinda Robnett, How Long? How Long? African American Women in the Struggle for Civil Rights (Oxford: Oxford University Press, 1997); See Raffaella Baritono, "La leadership è una pianta delicata': il concetto di leadership nel movimento delle donne americane fra Otto e Novecento," Ricerche di Storia Politica, V, 3 (2002), 351-364.

xlviii. Raffaella Baritono "'We must have eagle eyes': Eleanor Roosevelt, the United Nations and the World Trips of the 1950s," in Ferdinando Fasce, Maurizio Vaudagna, and Raffaella Baritono, 
eds., Beyond the Nation: Pushing the Boundaries of U.S. History from a Transatlantic Perspective (Turin: Otto editore, 2013), 61-89.

xlix. Eleanor Roosevelt, “Where Do Human Rights Begin?”, 27 March 1953, in Allida Black, ed., Courage in a Dangerous World. The Political Writings of Eleanor Roosevelt (New York: Columbia University Press, 2000), 190.

1. MacLeish to ER 27 December 1945, The Papers of Eleanor Roosevelt, 1945-1962, UN Correspondence and Publication, Part I, reel 1.

li. Interview with James Frederick Green By Emily Williams, January 21, 1980, Eleanor Roosevelt Oral History Transcripts, Roosevelt Study Center, Middelburg, NL.

lii. Eleanor Roosevelt, The Autobiography, 308.

liii. Helen Laville, Cold War Women.

liv. Andrew Johnstone, Dilemmas of Internationalism.

lv. Eleanor Roosevelt, The Autobiography, 306.

lvi. W.E.B. DuBois to M. McLeod Bethune, April 30, 1945, in Mary McLeod Bethune Papers, Part III, Series 1 , reel 4.

lvii. Walter White to ER, December 28, 1945 The Papers of Eleanor Roosevelt, 1945-1962, UN Correspondence and Publication, Part I, reel 1.

lviii. Mary L. Dudziak, Cold War Civil Rights: Race and the Image of American Democracy (Princeton: Princeton University Press, 2011); Carol Anderson, Eyes Off the Prize: The United Nations and the African American Struggle for Human Rights, 1944-1955 (Cambridge: Cambridge University Press, 2003).

lix. Eleanor Roosevelt to Walter White, 22 October 1947, in The Eleanor Roosevelt Papers, I, 634.

1x. A.G. Mezerik, "Negroes at UN's Door," The Nation, 13 December 1947.

1xi. Dean Acheson to Eleanor Roosevelt, 13 February 1952, Eleanor Roosevelt Papers, Roosevelt Library Archive, Hyde Park, N.Y., Box 4658 - Trip Files: Middle East and Pakistan, 1952 Folder E.R. Trip File 1952 (Feb-March), General Correspondences, Schedules, etc.

1xii. Daniel T. Rodgers, Atlantic Crossings: Social Politics in a Progressive Age (Cambridge: Harvard University Press, 1998).

lxiii. Reinhold Niebuhr, “American Liberals and British Labor," The Nation, June 8 1946, 683-4.

lxiv. See Dorothy F. Leet, "Recent Impressions of France and England. University Women Turn from Resistance to Rebuilding," Journal of the American Association of University Women, 39, 2 (January 1946), 73-76.

lxv. Helen Dwight Reid, "International Cooperation," Journal of the American Association of University Women, 38, 4 (summer 1945).

lxvi. Speech at Dinner in Honor of Mrs. Franklin Delano Roosevelt, United States Delegate to the General Assembly of the United Nations, Sponsored by the Women's Joint Congressional Committee, of Washington, D.C., Thursday Evening, March 14, 1946, Grand Ballroom of the Mayflower Hotel, in Bethune Papers, Pt. 3, Subject Files 1939-1955, reel 17

lxvii. Eleanor Roosevelt Speech for Oxford, November 13, 1948 The Papers of Eleanor Roosevelt, 1945-1962, UN Correspondence and Publication, Part I, reel 7

lxviii. Mark D. Alleyne, "The United Nations' Celebrity Diplomacy," The SAIS Review of International Affairs, 25, 1 (winter 2005), 175-185. 


\section{ABSTRACTS}

In 1945, Truman appointed Eleanor Roosevelt as a member of the American delegation to the first session of the United Nations in an effort to send a signal to the many associations who wanted to have a role in the redefinition of the post-war democratic order. ER' s commitment to peace and social justice was an expression of internationalism 'from below', which was convinced that the challenge to enlarge and make democracy more inclusive, more respectful of gender, racial, and ethnic differences had to be won not only in the domestic political sphere but also in the international one. The paper will explore the intrinsic contradiction which was at the root of ER' s engagement in the UN. On the one hand, she was conscious of her official status as American officer and the symbol of the American democratic model; on the other, her will to give expression and voice to the questions posed by American and European civic associations and their commitment to democracy, social justice and human rights in the growing Cold War climate provoked tensions and ambiguities that proved difficult to solve.

\section{INDEX}

Keywords: Clark Eichelberger, Cold War, Eleanor Roosevelt, Harry S. Truman, Internationalism, Public Diplomacy, United Nations

\section{AUTHOR}

\section{RAFFAELLA BARITONO}

University of Bologna 